\title{
Effects of Mevastatin on Electricity Generation in Microbial Fuel Cells
}

\author{
Naki Burak Akul ${ }^{1,2}$, Rumeysa Cebecioglu', Dilan Akagunduz ${ }^{1}$, Hakan Bermek ${ }^{3}$, \\ Murat Ozdemir ${ }^{4}$, Tunc Catal ${ }^{1,2 *}$ \\ ${ }^{1}$ Department of Molecular Biology and Genetics, Uskudar University 34662 Uskudar, Istanbul, Turkey \\ ${ }^{2}$ Istanbul Protein Research-Application and Innovation Center (PROMER), Uskudar University 34662 Uskudar, \\ Istanbul, Turkey \\ ${ }^{3}$ Department of Molecular Biology and Genetics, Istanbul Technical University 34467-Maslak, Istanbul, Turkey \\ ${ }^{4}$ Personalized Medicine Application and Research Center (KIMER), Uskudar University 34662 Uskudar, \\ Istanbul, Turkey
}

Received: 29 October 2020

Accepted: 16 February 2021

\begin{abstract}
Mevastatin is one of the pollutants in wastewater that is difficult to biodegrade. In this study, the issue of mevastatin biodegradation and simultaneous electricity generation using microbial fuel cells, which is one of the current sustainable technologies, was investigated. Effects of mevastatin on the performance of single-chamber air-cathode microbial fuel cells were investigated. On average, 0.2 volts of electricity was generated in microbial fuel cells in the presence of $5.6 \mu \mathrm{M}$ mevastatin, while mevastatin caused an important increase in coulombic efficiency, from $35 \pm 5 \%$ to $49 \pm 8$. More than $90 \%$ of the mevastatin was removed in microbial fuel cells in approximately four days. In conclusion, mevastatin that causes toxicity in wastewaters could potentially be treated using microbial fuel cells. Meanwhile, mevastatin may enhance electricity generation either through improved electron transfer or suppressed methanogenesis during microbial fuel cell operations.
\end{abstract}

Keywords: electricity, methanogenesis, mevastatin, microbial fuel cell, wastewater

\section{Introduction}

Microbial fuel cells (MFCs) are one of the most studied research topics in recent years, especially due to the decreasing need for alternative clean energy resources [1]. MFC is an environmentally friendly biotechnological device that produces electrical energy from industrial or household wastes while providing

*e-mail: tunc.catal@uskudar.edu.tr wastewater treatment [2]. With the advantages it offers, MFCs are expected to be part of our lives in near future since they are environmentally benign and able to carry out operations in ambient conditions [3, 4]. In this technology, electrogenic microorganisms are employed to produce electricity by breaking down substrates from waste materials. Thus, MFCs may also be utilized for bioremediation of various environmental contaminants $[5,6,1]$.

In MFC systems, nature of the microorganism community forming biofilms on the electrode surface may vary significantly [7, 8]. For example, 
MFCs using mixed microbial cultures suitable for wastewater treatment may also contain methanogenic microorganisms [8, 9]. These microorganisms are able to channel part of the electrons derived by other microorganisms into methane production, thereby reducing system efficiency by lowering electricity production. A great many studies were therefore focused on elimination of methanogenic microorganisms in MFCs. Methane production rate is lower in closed circuit operated MFCs than in open circuit operated MFCs [1011]. In MFCs, it was shown that power and performance increase is achieved using various antibiotics and methanogen inhibitors such as 2-bromoethane sulfonate [12]. It was also reported that mevastatin molecule inhibits the growth of methanogenic microorganisms such as Methanobrevibacter in microbial cultures [13].

Mevastatin is a hypolipidemic statin drug that works via inhibition of hydroxymethylglutaryl SCoA (HMG-CoA) reductase [14-15]. Although it inhibits the production of methane, it does not exhibit inhibitory effect on microorganisms that degrade complex polymers such as cellulose [14]. Mevastatin is prescribed as a cholesterol lowering and lipid regulator drug [16]. Drugs like mevastatin are partially metabolized, and contaminate the feces, urine and thus, the wastewaters. Mevastatin exists in wastewater at the concentration range of $0.15-1.25 \mu \mathrm{g} \quad \mathrm{L}^{-1}$ (0.3-3.2 $\mu \mathrm{M})$ [17]. Drug metabolites that get into surface waters from wastewater cause accumulation in a long term and adversely affect aquatic organisms [18]. Elimination of mevastatin from water bodies and wastewaters is of critical importance. However, there is no information about how a methane inhibitor, mevastatin, affects energy production performance, nor its degradation in MFCs.

Here, the effects of mevastatin on the performance of MFCs were reported for the first time, in terms of voltage production and effects on power and current density. Removal of mevastatin by microbial community in MFCs was also investigated using liquid chromatography tandem spectroscopy method (LC-MS/MS).

\section{Experimental}

\section{Chemicals}

Mevastatin $\left[\mathrm{C}_{23} \mathrm{H}_{34} \mathrm{O}_{5}\right]$ was obtained from Cayman Chemical Company (CAS. No. 73573-88-3, MI, USA). All other chemicals used in the study were analytical grade and obtained from commercial sources.

\section{MFC Construction}

In the study, single-chamber MFCs made of plexiglass were prepared and used as described before [4]. Electrodes were placed in MFCs and carbon cloth was used as the electrode materials. Both the surface area of anode (Lot: 14032102, FuelCells, Texas, USA) and cathode (CTO32414, FuelCells, Texas, USA) was $7 \mathrm{~cm}^{2}$. While preparing the air cathode, the surface facing inside was coated with platinum $\left(0.5 \mathrm{mg} / \mathrm{cm}^{2}\right)$ and nafion (CAS. No: 31175, Sigma-Aldrich, USA), while the exterior was waterproofed using PTFE [19].

\section{Inoculation and Operation of MFCs}

Electroactive microorganisms used in MFCs were enriched from activated sludge from a local advanced biological wastewater treatment plant (Pasakoy, Istanbul, Turkey). Microbial fuel cells were fed standard medium with glucose as carbon source $\left(1.2 \mathrm{~g} \mathrm{~L}^{-1}\right)$. The medium was composed of the following ingredients: $\mathrm{NaH}_{2} \mathrm{PO}_{4} .7 \mathrm{H}_{2} \mathrm{O}\left(15.47 \mathrm{~g} \mathrm{~L}^{-1}\right), \mathrm{Na}_{2} \mathrm{HPO}_{4} \cdot \mathrm{H}_{2} \mathrm{O}\left(5.84 \mathrm{~g} \mathrm{~L}^{-1}\right)$, $\mathrm{NH}_{4} \mathrm{Cl}\left(0.31 \mathrm{~g} \mathrm{~L}^{-1}\right), \mathrm{KCl}\left(0.13 \mathrm{~g} \mathrm{~L}^{-1}\right)$, a vitamin stock solution $\left(12.5 \mathrm{~mL} \mathrm{~L}^{-1}\right)$ and a mineral stock solution (12.5 $\mathrm{mL} \mathrm{L}^{-1}$ ) as reported previously [20]. $\mathrm{pH}$ of the medium was adjusted to 7 .

Microbial fuel cells were run in batch mode and fed with fresh media when the voltage production dropped below $50 \mathrm{mV}$. After reproducible voltage production was observed, mevastatin was added to the medium. Mevastatin was prepared as stock solution in ethanol to $\left(5 \mathrm{mg} \mathrm{mL}^{-1}\right)$. Two different concentrations of mevastatin were tested in the study. The same concentration of mevastatin was repeatedly tested in batch operations and the voltage production was monitored. All operations of microbial fuel cells were carried out at ambient conditions.

\section{Analyses and Calculations}

The electrodes of the MFCs were connected to the data acquisition system (Keithley KickStart Software, Version 1.9.8.21, Tektronix Company, Beaverton, Oregon, USA) via titanium cables and the operation was started with a $980 \Omega$ external resistance. System recorded voltage data every $11 \mathrm{~min}$. Samples from MFCs were collected, filtered and subjected to further analysis. A liquid chromatography-tandem mass spectrometry (LC-MS/MS) (Agilent Technologies 1200 Series 6410, Santa Clara, CA, USA) was used to measure the concentrations of mevastatin [21].

Power density, which is one of the most important parameters to evaluate the performances of MFCs, was calculated using the formula; $\mathrm{P}=\mathrm{IV} / \mathrm{A}$, where $\mathrm{I}$ is the current (A), $\mathrm{V}$ voltage $(\mathrm{V})$, and $\mathrm{A}$ is the surface area of the electrode $\left(\mathrm{cm}^{2}\right)$ [21]. Coulombic efficiency (CE), which shows how much of the electrons supplied to the system is recovered electrically, was calculated as; $\mathrm{CE}=\mathrm{CP} / \mathrm{CTi} \times 100 \%$, where $\mathrm{CP}$ is the total coulombs calculated by integrating the current over time and CTi is the theoretical amount of coulombs that could be extracted from the carbon source [22]. All experiments were repeated at least twice, and standard deviations were calculated based on the mean of two independent measurements $(\mathrm{n}=2)$. 
Chemical oxygen demand (COD) analyses were performed on samples before and after the operation using standard methods [23].

\section{Results and Discussion}

In previous studies, the concentrations of lipid regulator and cholesterol lowering statin-group drugs including mevastatin in wastewaters may vary from ng $\mathrm{L}^{-1}$ levels to $\mathrm{g} \mathrm{L}^{-1}$ levels in a study analyzing hospital wastewater samples. Previously, these drugs including mevastatin were measured in wastewaters at concentrations such as $54.3 \mathrm{~g} \mathrm{~L}^{-1}, 21.6 \mathrm{~g} \mathrm{~L}^{-1}$ and $1.75 \mathrm{~g} \mathrm{~L}^{-1}$ on a daily basis [18]. The stability of atorvastatin, rosuvastatin and simvastatin drugs, which belong to the group of HMG-CoA reductase inhibitors (statins) similar to mevastatin was also published [24]. To investigate their removal from wastewater, activated sludge samples were designed to contain drugs at a concentration of $1 \mathrm{~g} \mathrm{~L}^{-1}$ [24-25]. Atorvastatin and simvastatin removal was previously measured, and their concentrations were found as $1.56 \mu \mathrm{g} \mathrm{\textrm {L } ^ { - 1 }}$ and $1.23 \mu \mathrm{g} \quad \mathrm{L}^{-1}$ (3.9-3.1 $\left.\mu \mathrm{M}\right)$, respectively [26]. In wastewater models used in the study, however, $1 \mathrm{mg} \mathrm{L}^{-1}$ as the initial concentration was chosen [26]. The approximate concentration of mevastatin in wastewater has been reported as 150-1250 $\mathrm{ng} \mathrm{L}^{-1}(0.3-3.2 \mu \mathrm{M})$ [26]. In the current study, therefore the concentrations for mevastatin was selected to be in the range or even above the concentrations used in the previous studies. It was shown that MFCs were successfully capable of degrading even higher concentrations than those tried before.

Microbial fuel cells produced approximately $0.22 \mathrm{~V}$ of constant electricity with glucose as the carbon source. Once the stable production was observed through several batches, mevastatin was introduced at a concentration of $5.6 \mu \mathrm{M}$. The presence of mevastatin at this concentration caused negligible effect on voltage production by dropping to $0.21 \mathrm{~V}$, however, it took longer to complete a batch cycle (105 hours instead of 55 hours). When the concentration of mevastatin was increased to $10 \mu \mathrm{M}$, another slight decrease (to $0.2 \mathrm{~V}$ ) was detected in voltage production. These results showed that administration of mevastatin does not notably inhibit voltage production (Fig. 1).

Mevastatin was degraded by $98.6 \%$ and $90 \%$ in the MFCs at concentrations of $5.6 \mu \mathrm{M}$ or $10 \mu \mathrm{M}$, respectively (Table 1, Fig. 2). These results indicated that mevastatin could be efficiently removed from wastewaters using MFC technology. Metabolites eluted at around $2.5 \mathrm{~min}$ represent an unknown substance similar to mevastatin molecule. In the presence of $5.6 \mathrm{mM}$ mevastatin, the chemical oxygen demand (\%) removal was 56 \pm 5.6 , when the concentration was increased to $10 \mathrm{mM}$, the removal increased to $86 \pm 1$.6. Researchers often focused on removing antibiotics and heavy metals toxicity from wastewater, using MFC technology [2]. Studies on the elimination of lipid-regulating drugs from wastewaters are rare in the literature. The removal of two lipidregulating drugs from synthetic wastewater by a novel wastewater treatment model was studied, and it was reported that atorvastatin $\left(1.56 \mu \mathrm{g} \mathrm{L}^{-1}\right)$ and simvastatin (1.23 $\left.\mu \mathrm{g} \mathrm{L}^{-1}\right)$ were removed by $85-90 \%$ [26].

In the presence of $5.6 \mu \mathrm{M}$ mevastatin, power densities and current densities were also minutely influenced, maximum power density increased from $67 \pm 1 \mathrm{~mW} / \mathrm{m}^{2}$ to $68 \pm 1 \mathrm{~mW} / \mathrm{m}^{2}$ while the maximum current density did not change $\left(0.031 \mathrm{~mA} / \mathrm{cm}^{2}\right)$ when compared to the control. When mevastatin was raised from $5.6 \mu \mathrm{M}$ to $10 \mu \mathrm{M}$, these values changed to $61 \pm 3 \mathrm{~mW} / \mathrm{m}^{2}$ and $0.029 \mathrm{~mA} / \mathrm{cm}^{2}$, respectively (Table 1). Interestingly, however, administration of mevastatin at a concentration of $5.6 \mathrm{mM}$ resulted in an increase in coulombic efficiency with respect to the starting conditions. Nevertheless, increasing the concentration to $10 \mu \mathrm{M}$ resulted in a decrease. This suggests that, mevastatin

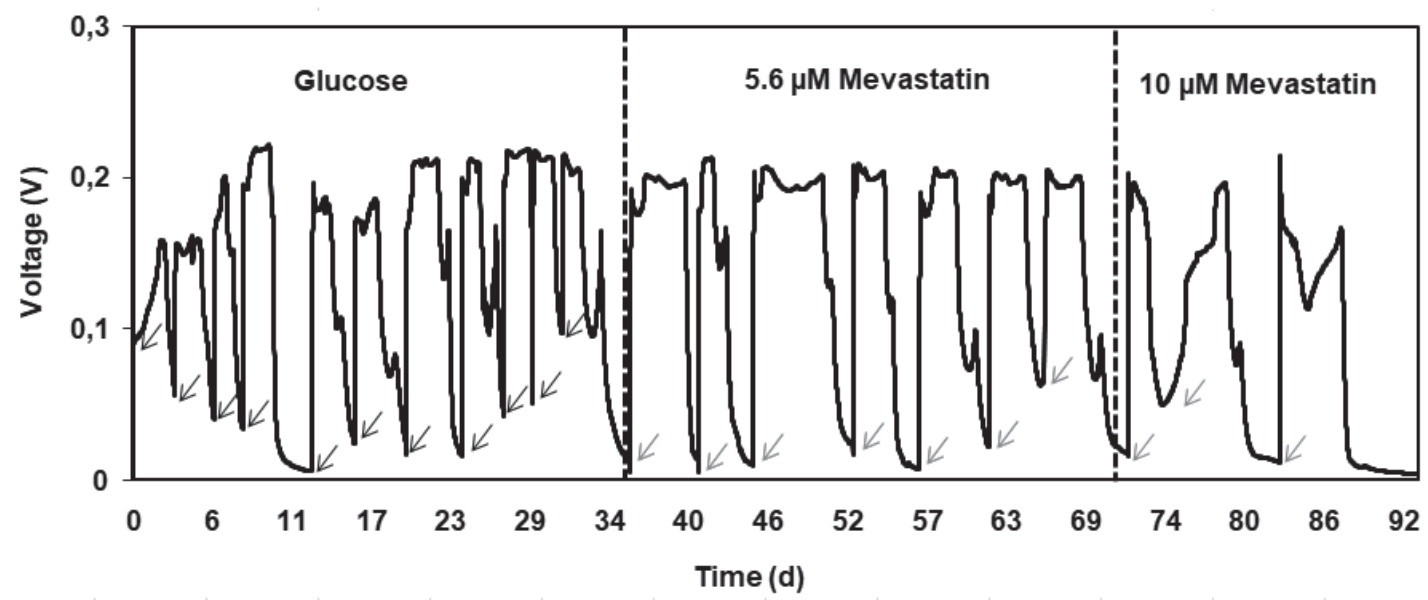

Fig. 1. Voltage production in MFCs in the absence and presence of mevastatin $(0 \mu \mathrm{M}, 5.6 \mu \mathrm{M}$ and $10 \mu \mathrm{M})$. Arrows indicate the addition of fresh medium. 

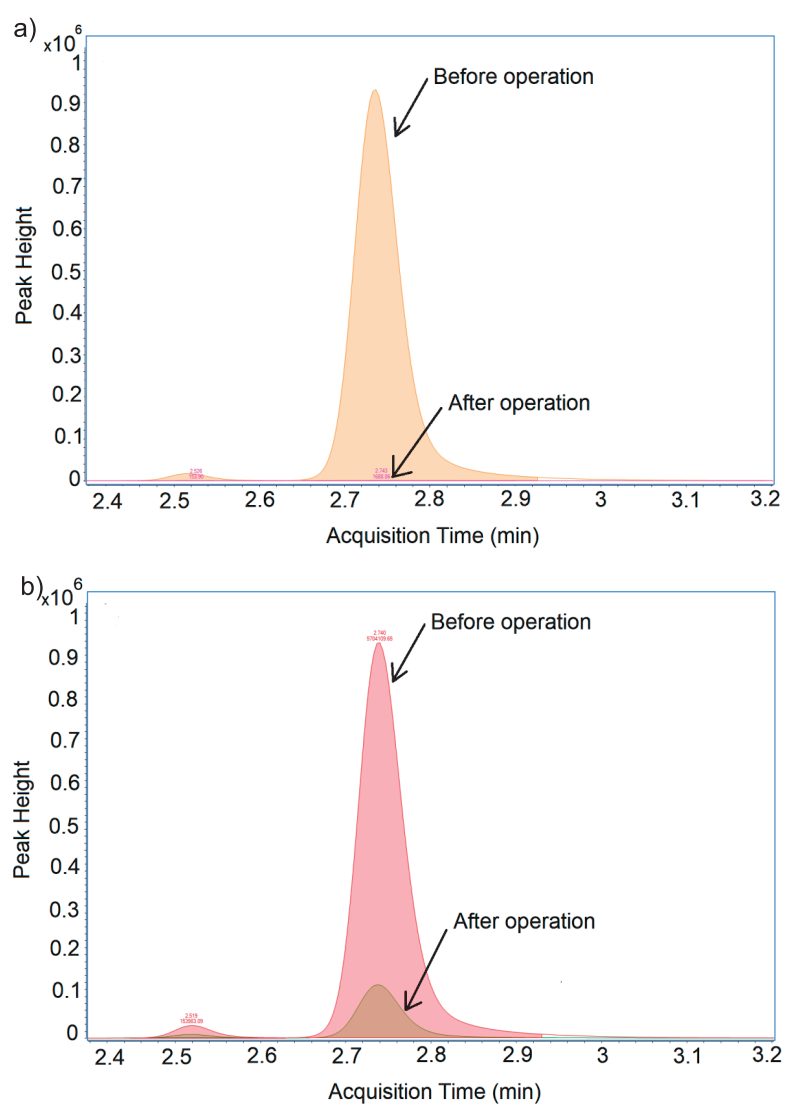

Fig. 2. LC-MS/MS chromatogram of before and after operation in MFCs using 5.6 $\mu \mathrm{M}$ Mevastatin a). LC-MS/MS chromatogram of before and after operation in MFCs using and $10 \mu \mathrm{M}$ mevastatin b). Arrows indicate the mevastatin peaks.

at $5.6 \mu \mathrm{M}$ increased electron recovery from the system compared to control MFCs. One of the reasons for this increase in the coulombic efficiency may have been the suppression of methanogenic microorganisms with the application of mevastatin. It was previously reported that in the MFCs operated in ambient conditions not favored by methanogenic microorganisms, coulombic efficiency values also increased [11]. These results imply that mevastatin could reduce methanogenic acitivty in MFCs and cause an increase in coulombic efficiency values.

Researchers often focused on their work with removing antibiotics and heavy metals from wastewater [27-30]. Studies on the removal of lipid-regulating drugs are not very common in the literature. The removal of two lipid-regulating drugs dissolved in synthetic wastewater by biodegradation method was previously investigated [26]. It was reported reported that atorvastatin $\left(1.56 \mu \mathrm{g} \mathrm{L}^{-1}\right)$ and simvastatin $\left(1.23 \mu \mathrm{g} \mathrm{L} \mathrm{L}^{-1}\right)$ drugs were removed by $85-90 \%$. In another study elimination of three lipid regulating drugs (clofibric acid, bezafibrate, gemfibrozil) from wastewater was investigated using two sewage treatment plants. It was reported that $60-70 \%$ of clofibric acid and more than $75 \%$ of bezafibrate and gemfibrozil were removed [31]. Due to its recalcitrant nature, however, mevastatin elimination via conventional wastewater treatment was reported to be as low as 34\% [32]. Using MFCs, however, we were able to demonstrate almost complete removal of mevastatin. This result is therefore highly promising for potential use of MFCs for treatment of wastewaters containing mevastatin as well as other statins or similar biochemicals, in addition to electricity production.

\section{Conclusions}

In the current study, degradation of mevastatin as well as its effects on electricity generation in single-chamber MFCs were investigated. Voltage generation was around $0.2 \mathrm{~V}$ in the presence of mevastatin when the drug concentration was increased from $0 \mathrm{mM}$ to $5.6 \mu \mathrm{M}$, the coulombic efficiency increased from $35 \pm 5 \%$ to $49 \pm 8 \%$. Mevastatin was nearly completely degraded at this concentration. In conclusion, MFCs could be an efficient tool in wastewaters with mevastatin, with an added value of electricity generation. Moreover, mevastatin may enhance electricity generation during MFC operations either through improved electron transfer or suppressed methanogenesis which needs further studies involving microbial community analysis on biofilm on the electrode surfaces.

\section{Acknowledgements}

This study was supported by the Scientific and Technological Research Council of Turkey (TÜBITTAK) (Project No. 113Z589).

Table 1. MFC performance using different concentrations of Mevastatin ( $0-10 \mu \mathrm{M})$.

\begin{tabular}{|c|c|c|c|c|}
\hline Concentration $(\mu \mathrm{M})$ & Power density $\left(\mathrm{mW} / \mathrm{m}^{2}\right)$ & Current density $\left(\mathrm{mA} / \mathrm{cm}^{2}\right)$ & Coulombic efficiency $(\%)$ & MVS removal $(\%)$ \\
\hline 0 & $67 \pm 1$ & $0.031 \pm 0$ & $35 \pm 5$ & n.a. \\
\hline 5.6 & $68 \pm 1$ & $0.031 \pm 0$ & $49 \pm 8$ & $98.6 \pm 0.9$ \\
\hline 10 & $61 \pm 3$ & $0.029 \pm 0$ & $30 \pm 8$ & 90 \\
\hline
\end{tabular}

*MVS: Mevastatin

n.a.: not applicable 


\section{Conflict of Interest}

The authors declare no conflict of interest.

\section{References}

1. CATAL, T., FAN, Y., LI, K., BERMEK, H., LIU, H. Effects of furan derivatives and phenolic compounds on electricity generation in microbial fuel cells. Journal of Power Sources, 180, 2008.

2. CATAL T., YAVASER S., ENISOGLU-ATALAY V., BERMEK H., OZILHAN S., Monitoring of neomycin sulfate antibiotic in microbial fuel cells. Bioresource Technology, 268, 2018.

3. ATASEVER ARSLAN B., AKDOGAN E., CEBECI F.C., CATAL T. Bioelectricity generation using human neuronal-like cells in single chamber biofuel cells. Journal of Cleaner Production, 271, 2020.

4. BERMEK H., CATAL T., AKAN S.S., ULUTAS M.S., KUMRU M., ÖZGÜVEN M., LIU H., ÖZÇELIK, B., AKARSUBASI A.T. Olive mill wastewater treatment in single-chamber air-cathode microbial fuel cells. World Journal of Microbiology and Biotechnology, 30, 2013.

5. CATAL T., KUL A., ENISOGLU-ATALAY V., BERMEK H., OZILHAN S., TARHAN N. Efficacy of microbial fuel cells for sensing of cocaine metabolites in urine-based wastewater. Journal of Power Sources, 414 (1-7), 2019.

6. CATAL T., LI K., BERMEK H., LIU H. Electricity production from twelve monosaccharides using microbial fuel cells, Journal of Power Sources, 175 (1), 2008.

7. ABOURACHED C., CATAL T., LIU H. Efficacy of singlechamber microbial fuel cells for removal of cadmium and zinc with simultaneous electricity production. Water Research, 51, 2014.

8. KUMRU M., EREN H., CATAL T., AKARSUBASI A.T., BERMEK H. Study of azo dye decolorization and determination of cathode microorganism profile in aircathode microbial fuel cells, Environmental Technology, 33 (16-18), 2012.

9. CATAL T., FAN Y., LI K., BERMEK H., LIU H. Utilization of mixed monosaccharides for power generation in microbial fuel cells. Journal of Chemical Technology and Biotechnology, 86 (4), 2011.

10. CATAL T., KAVANAGH P., O'FLAHERTY V., LEECH D. Generation of electricity in microbial fuel cells at subambient temperatures, Journal of Power Sources, 196 (5), 2010.

11. ZHUANG L., CHEN Q., ZHOU S., YUAN Y., HAORAN Y. Methanogenesis Control using 2-Bromoethanesulfonate for Enhanced Power Recovery from Sewage Sludge in Air-cathode Microbial Fuel Cells. International Journal of Electrochemical Science, 7, 2012.

12. LIU H., WANG J., WANG A., CHEN J. Chemical inhibitors of methanogenesis and putative applications. Applied Microbiology and Biotechnology, 5, 2011.

13. MILLER, T.L., WOLIN, M.J. Inhibition of growth of methane-producing bacteria of the ruminant forestomach by hydroxymethylglutaryl $\mathrm{SCoA}$ reductase inhibitors. Journal of Dairy Science, 84 (6), 2001.

14. GOTTLIEB K., WACHER V., SLIMAN J., PIMENTEL M. Inhibition of methanogenic archaea by statins as a targeted management strategy for constipation and related disorders. Alimentary Pharmacology \& Therapeutics, 43 (2), 2016.
15. SYEDAB M.B., PONNUSAMYA T. Bioconversion of mevastatin to pravastatin by various microorganisms and its applications. Biocatalysis and Agricultural Biotechnology, 13, 2018.

16. GROS M., PETROVIĆ M., BARCELÓ D. Development of a multi-residue analytical methodology based on liquid chromatography-tandem mass spectrometry (LCMS/MS) for screening and trace level determination of pharmaceuticals in surface and wastewaters. Talanta, 70 (4), 2006.

17. OTTMAR K.J., COLOSI L.M., SMITH J.A. Sorption of Statin Pharmaceuticals to Wastewater-Treatment Biosolids, Terrestrial Soils, and Freshwater Sediment. Journal of Environmental Engineering, 136 (3), 2010.

18. RADJENOVIC J., PETROVIC M., BARCELÓ D. Analysis of pharmaceuticals in wastewater and removal using a membrane bioreactor. Analytical and Bioanalytical Chemistry, 387 (4), 2007.

19. CHENG S., LIU H., LOGAN B.E. Increased performance of single-chamber microbial fuel cells using an improved cathode structure. Electrochemistry Communications, 8 (3), 2006.

20. LOVLEY D.R., PHILLIPS E.J.P. Novel mode of microbial energy metabolism: organic carbon oxidation coupled to dissimilatory reduction of iron or manganese. Appl. Environ. Microbiol. 54, 1988.

21. YANG D.H.D., MURPHY M.A., ZHANG S. Highly Sensitive Detection of Pharmaceuticals and Personal Care Products (PPCPs) in Water Using an Agilent 6495 Triple Quadrupole Mass Spectrometer. Agilent Technologies, 2014.

22. YAN D., SONG X., WENG B., YU Z., BI W., WANG J. Bioelectricity generation from air-cathode microbial fuel cell connected to constructed wetland. Water Science Technology, 78 (9), 2018.

23. AMERICAN PUBLIC HEALTH ASSOCIATION, AMERICAN WATER WORKS ASSOCIATION, WATER POLLUTION CONTROL FEDERATION. In: Standard Methods for the Examination of Water and Wastewater, 18th ed. American Public Health Association, Washington, DC. Agilent Technologies, 1992.

24. SULAIMAN S., KHAMIS M., NIR S., LELARIO F., SCRANO L., BUFO S.A., MECCA G., KARAMAN R. Stability and removal of atorvastatin, rosuvastatin and simvastatin from wastewater. Environmental Technology, 24 (36), 2015.

25. SANTOS M.M., RUIVO R., LOPES-MARQUES M., TORRES CARMEN T.B., CASTRO L.F.C., NEUPARTH T. Statins: an undesirable class of aquatic contaminants? Aquatic Toxicology, 174, 2016.

26. OTTMAR K.J., COLOSI L.M., SMITH J.A. Fate and transport of atorvastatin and simvastatin drugs during conventional wastewater treatment. Chemosphere, 88 (10), 2012.

27. KAUSHIK A., SINGH A. Metal removal and recovery using bioelectrochemical technology: The major determinants and opportunities for synchronic wastewater treatment and energy production. Journal of Environmental Management, 270, 2020.

28. CHENG D., HAO NGO H., GUO W., LEE D., LONG NGHIEM D., ZHANG J., WANG J. Performance of microbial fuel cell for treating swine wastewater containing sulfonamide antibiotics. Bioresource Technology, 331, 2020.

29. WEN H., ZHU H., YAN B., XU Y., SHUTES B. Treatment of typical antibiotics in constructed wetlands integrated 
with microbial fuel cells: Roles of plant and circuit operation mode. Chemosphere, 250, 2020.

30. ONDON B.S., LI S., ZHOU Q., LI F. Simultaneous removal and high tolerance of norfloxacin with electricity generation in microbial fuel cell and its antibiotic resistance genes quantification. Bioresource Technology, 304, 2020.

31. HUANG Q., YU Y., TANG C., ZHANG K., CUI J., PENG X. Occurrence and behavior of non-steroidal anti- inflammatory drugs and lipid regulators in wastewater and urban river water of the Pearl River Delta, South China. Journal of Environmental Monitoring, 13 (4), 2011.

32. OTTONI C.A., SIMÕES M.F., SANTOS J.G., PEIXOTO L., MARTINS C.R., SILVA B.P., MAIORANO A.E. Application of microbial fuel cell technology for vinasse treatment and bioelectricity generation. Biotechnology Letters, 41, 2018. 